\title{
Introduction: Diversifying the black diggers' histories
}

Noah Riseman

When I started researching Aboriginal and Torres Strait Islander military service history in 2004, this was a very niche academic area. David Huggonson did some work in the 1980s and 1990s on the First World War, and Robert Hall's canonical texts The Black Diggers (1989) and Fighters from the Fringe (1995) had set a dominant narrative of the First and Second World War experiences: notwithstanding regulations explicitly prohibiting enlistment of persons 'not substantially of European origin or descent', Aboriginal and Torres Strait Islander people managed to circumvent the rules and served in both conflicts. For those men and women enlisted in regular units, it was largely an egalitarian experience - often for the first times in their lives - yet they returned home to continuing discrimination. Huggonson estimated about 400 Aboriginal men served in the First World War; Hall estimated approximately 3,000 Aboriginal people and 850 Torres Strait Islanders formally served in the Second World War, not to mention the hundreds more who served in informal, labouring capacities in remote northern Australia. ${ }^{1}$ Some local histories enhanced this dominant narrative of participation, including the works of scholars such as Heather Goodall, Kay Saunders and Elizabeth Osborne. ${ }^{2}$ Now the estimates have increased to at least 1,000 and 5,000 Aboriginal and Torres Strait Islander personnel in the First and Second World Wars respectively. These men and women came from diverse cultural, educational, linguistic, regional and employment backgrounds.

$1 \quad$ Huggonson 1993, 1989; Hall 1997, 1995.

2 Goodall 1987; Saunders 1995; Osborne 1997. 
Until the 2000s, it was not solely academics who had focused their research on other areas of Indigenous and/or military history; so, too, was there little public interest in Aboriginal and Torres Strait Islander military service. Yet there was a growing movement to recognise Aboriginal and Torres Strait Islander defence, spearheaded primarily by Aboriginal and Torres Strait Islander veterans. As one Aboriginal person I spoke to early in my doctoral research pointed out to me, Aboriginal and Torres Strait Islander communities have been well aware of the histories of their men and women in the Australian Defence Force (ADF) and its predecessors. Indeed, several Indigenous publications told the histories of their communities in the military. ${ }^{3}$ It was non-Indigenous people who knew little or nothing about it. That point has always stuck with me over the years both when researching and writing in this area.

In the 2000s, Aboriginal and Torres Strait Islander groups pushed for greater recognition and were successful in numerous endeavours: the Aboriginal and Torres Strait Islander Veterans Association led Perth's 2001 Anzac Day march; Honouring Indigenous War Graves was founded in 2005 and has been performing ceremonies at the gravesites of deceased Aboriginal servicemen and women across Western Australia; in 2006, Aunty Dot Peters lobbied Victoria's Returned and Services League (RSL) to sponsor a commemorative service at Melbourne's Shrine of Remembrance during Reconciliation Week; since 2007 the Department of Veterans' Affairs has sponsored services across the major capital cities; 2007 also marked the first annual Coloured Diggers March in Redfern on Anzac Day. Since the 2010s, there has been a growing movement for memorials to Aboriginal and Torres Strait Islanders military service. Adelaide's memorial was completed in 2013 and Sydney dedicated a sculpture commemorating Indigenous military service in March 2015. Indigenous military service history has also gradually infiltrated Australia's popular consciousness through cultural events such as the play Black Diggers, premiering in Sydney and Brisbane in 2014 and touring Australia in 2015. There is much greater media interest in the area too - including SBS programs like Living Black, NITV specials on Anzac Day and news features on the $\mathrm{ABC}$ and local radio in particular. There are resources available online through the Australian War Memorial, the Australian Institute for Aboriginal and Torres Strait Islander Studies (AIATSIS) and other websites.

Accompanying the growing popular interest in Aboriginal and Torres Strait Islander military history, historians, too, have focused more on this topic over the last decade. ${ }^{4}$ This growing body of work from both Indigenous and nonIndigenous historians has expanded the dominant narratives of Aboriginal and Torres Strait Islander military service, addressing issues including Vietnam War

\footnotetext{
Jackomos and Fowell 1993; Kartinyeri 1996; Bray et al. 1995.

See Riseman 2014.
} 
service, the links between military service and activism in the interwar period, Aboriginal women on the homefront and contextualising Australia's experience within other Anglo-settler societies. Research into Aboriginal and Torres Strait Islander military service continues both at the grassroots level through the work of public historians, and through major initiatives such as the Australian Research Council Linkage project 'Serving Our Country: A history of Aboriginal and Torres Strait Islander people in the Defence of Australia', in partnership with the Department of Veterans' Affairs, Australian War Memorial, the National Archives of Australia and the Department of Defence.

Aboriginal History was early on a pioneer in highlighting this area of research, publishing a special issue in 1992 on Aboriginal military service as the field was in its infancy. ${ }^{5}$ As Australia commemorates the centenary of the First World War, it is timely that this special section of Aboriginal History continues this investigation into Aboriginal and Torres Strait Islander military history. More importantly, the articles in this special section focus on the lived experiences of Aboriginal and Torres Strait Islander service personnel and their families. The articles expand our understanding that wars' impact on Indigenous communities was neither uniform nor even. Each of the authors in this collection approaches the topic of Indigenous military service through different angles previously unexplored, and as such they provide new understandings of the diverse ways that military service affected Aboriginal and Torres Strait Islander Australians.

First in this collection is John Maynard's article on Aboriginal participation in the South African Anglo-Boer War. For years, commemorations of Indigenous military service have assumed their participation in all conflicts from the Anglo-Boer War through to the present, yet it is only in the last few years that historians have been able to point to concrete evidence of Aboriginal men's participation in the Anglo-Boer War. As Maynard argues, much of the speculation from the past few years about numbers of Aboriginal trackers, as well as the allegation some were left behind in South Africa, contains grains of truth, but are actually exaggerated claims. Even so, Maynard demonstrates the ways in which policymakers, non-Indigenous Australians and Aboriginal people positioned military service as an opportunity with different meanings attached for each advocate.

The theme of mateship underpins Philippa Scarlett's article about both the breadth of Aboriginal servicemen's backgrounds, as well as her complex evaluation of an 'egalitarian' experience. Scarlett draws on service records and newspaper articles to demonstrate that whilst current discourse tries to include Aboriginal diggers in the Anzac legend of 'mateship', in actuality they were 
not seen as equal. Instead, supposed equality on the front was still an exercise in white power, willing to elevate Indigenous Australians overseas, but just as willing to reposition them as inferior upon their return to civilian society. This analysis offers new insights into a recurring query among histories of Aboriginal people in the First World War: why prejudice and discrimination endured after the war, even amongst the ex-services' community.

Tasmanian Aboriginal participation in the First World War and the returned servicemen's post-war experiences are, as Andrea Gerrard and Kristyn Harman argue, quite distinct from the experiences of those from other states. Because popular discourse contended there were no more Tasmanian Aboriginal people (although the soldiers were recognised as being of Tasmanian Aboriginal descent) and there was no state protection board, Aboriginal veterans were not necessarily denied benefits as in the other states. Moreover, a complex situation arose through the intersections of a colour blind repatriation regime and a public that still stigmatised so-called 'half-castes' for their Aboriginal heritage. Gerrard and Harman argue that amidst these intersections, the problems Tasmanian Aboriginal people encountered with the repatriation regime had more to do with structural issues including distance and practical access, some of which were legacies of colonisation, rather than racial discrimination per se.

Jessica Horton's research addresses the important issue of repatriation benefits after the First World War, focusing on the Gunditjmara in western Victoria. It has long been understood that government policies obstructed Aboriginal access to benefits including soldier settlement, and the tale of Lake Condah Aboriginal Reserve being closed and given to non-Indigenous soldier settlers is a prominent example. Yet, as Horton argues, using letters from Aboriginal returned servicemen and their families, the Gunditjmara resisted the Aborigines Protection Board's attempts to curtail their entitlements and in some cases were successful in securing their benefits. Her article not only devotes significant attention to Aboriginal agency and how returned servicemen positioned their veterans' status, but also challenges the notion of complete Aboriginal powerlessness in the face of government oppression.

Finally, Kristyn Harman looks at gender and race relations in the Second World War through the prism of the Aborigines Uplift Society's national comforts auxiliary. This organisation recruited white women to 'adopt' Aboriginal soldiers and to send items such as socks to Aboriginal men on the front, and they in turn corresponded with the women in Australia. Harman's analysis of the letters and newspaper articles reveals ways in which even from far away, Aboriginal soldiers could challenge white women's (mis)perceptions of Aboriginal Australians. Harman also addresses the role that Aboriginal women 
played across a range of Australian comfort funds, including a focus on the race relations with white women and authorities near Cummeragunja in New South Wales.

All the articles in this special section offer new insights into the history of Aboriginal and Torres Strait Islander people in the armed forces, extending from the South African Anglo-Boer War through to the Second World War, contributing to the increasingly complex and nuanced readings of Indigenous military service that are emerging in this growing field of academic inquiry. They also challenge our understandings of how Indigenous Australians coped during the aftermath of the First World War, highlighting in particular the necessity to focus on specific times and places in order to understand better local specificities and regional variations. It was not simply a common story that extended across the nation. These articles show the value and importance of in-depth research and analysis in this area, to deepen our knowledge of the history, rather than being content to trot out the same statements that circulate about Indigenous Australians' service. There are as many Aboriginal and Torres Strait Islander histories of military service as there are Aboriginal and Torres Strait Islander people, and this special section continues to fill those gaps in academic histories and Australians' popular memories of those experiences. Lest we forget.

\section{References}

Aboriginal History 16(1), 1992.

Bray, George, Kenny Laughton and Pat Forster (eds) 1995, Aboriginal Ex-Servicemen of Central Australia, IAD Press, Alice Springs.

Goodall, Heather 1987, 'Not such a respected soldier: The impact of World War 1 on Aborigines in New South Wales', Teaching History 21(4): 3-6.

Hall, Robert 1995, Fighters from the Fringe: Aborigines and Torres Strait Islanders Recall the Second World War, Aboriginal Studies Press, Canberra.

1997, The Black Diggers: Aborigines and Torres Strait Islanders in the Second World War, second edition, Aboriginal Studies Press, Canberra.

Huggonson, David 1989, 'The dark diggers of the AIF', The Australian Quarterly 61(3): 352-357.

1993, Aboriginal diggers of the 9th Brigade. First AIF-Australia. Army. Australian Imperial Force, (1914/1921)', Journal of the Royal Australian Historical Society 79(3-4): 214-225. 
ABORIGINAL HISTORY VOL 392015

Jackomos, Alick and Derek Fowell 1993, Forgotten Heroes: Aborigines at War from the Somme to Vietnam, Victoria Press, Melbourne.

Kartinyeri, Doreen 1996, Ngarrindjeri ANZACS, South Australian Museum and Raukkan Council, Adelaide.

Osborne, Elizabeth 1997, Torres Strait Islander Women and the Pacific War, Aboriginal Studies Press, Canberra.

Riseman, Noah 2014, 'The rise of Indigenous military history', History Compass 12(12): 901-911.

Saunders, Kay 1995, 'Inequalities of sacrifice: Aboriginal and Torres Strait Islander labour in northern Australia during the Second World War', Labour History 69(2): 131-148. 
This text is taken from Aboriginal History, Volume 39, 2015, edited by Liz Conor, published 2015 by ANU Press,

The Australian National University, Canberra, Australia. 